\title{
Питання психології
}

DOI: $10.33099 / 2617-6858-2019-52-2-33-39$

Гичко Ю. аспірант Уманського державного педагогічного університету імені Павла Тичини ORSID ID 0000000212511129

\section{ЕМОЦІЙНА КОМПЕТЕНТНІСТЬ ОСОБИСТОСТІ У ПСИХОЛОГІЧНОМУ ДИСКУРСІ}

У статті презентовано результати аналізу наукового доробку вчених, зусилля яких спрямовані на вивчення емоційної компетентності особистості. Зокрема, зазначається, що синтезуючи здібності людини до усвідомлення власних емочій $і$ розуміння емочій інших людей, емоційна компетентність забезпечує збереження душевного балансу, духовну цілісність $і$ здоров'я особистості, проявляючись у ціннісній диференціації емоційних станів та емоиійній саморегуляиії діяльності і спілкування. Розвиток иієї компетентності складна робота, але саме ия робота дає найбільші результати, саме вона підвищує особисту ефективність. Психолог із високим рівнем розвитку емоційної компетентності має виражені здібності до розуміння власних емоцій та емоцій інших людей, до управління емоційною сферою, щзо обумовлює більш високу адаптивність і ефективність у спілкуванні. Емоційна компетентність, як складова професійної компетентності, $\epsilon$ сукупністю емоційних і соціальних здібностей, таких як здібності до розуміння власних емоцій та емоцій інших людей, до управління емоційною сферою. Усі структурні компоненти емоційної компетентності взаємозв'язані, і їхня тісна взаємозалежність сприяє ефективній міжособистісній взаємодії. Інструментами розвитку емоційної компетентності є книги, тренінги, коучинг.

Ключові слова: емоційна компетентність; особистість; емоційні стани; емоиійна саморегуляиія; діяльність, спілкування.

\section{Актуальність дослідження.}

Розпізнавання власних емоцій - перший крок у розвитку EQ. Часто людина утруднюється описати вербально ті почуття, які відчуває. Існує безліч емоцій, у кожної багато рівнів інтенсивності, тому емоційна усвідомленість видається доволі нелегким завданням. Чим чіткіше людина навчиться визначати кожну власну емоцію, тим ширшими будуть ii можливості 3 управління власною поведінкою. Дані зарубіжних досліджень у сфері емоційної компетентності свідчать про те, що управління емоціями - це навичка, яку можна напрацьовувати i розвивати впродовж усього життя людини [13]. Через це проблема емоційної компетентності $\epsilon$ однією 3 найважливіших психологопедагогических проблем, актуальних для особистісного i професійного розвитку сучасного психолога. Емоційна компетентність - це вміння усвідомлювати власні емоції та емоції партнера по спілкуванню, аналізувати їх та управляти ними із метою вибору оптимальної поведінки у конкретній ситуації. Розвинені навички емоційної компетентності дозволяють психологу розглядати власні емоції та емоції тих, 3 ким він працює як управлінський ресурс i завдяки цьому підвищувати ефективність власної діяльності. Специфіка праці психолога полягає у тому, що йому необхідно протистояти професійним труднощам, управляти власним емоційним станом, визначати особливості власних дій, проявляти перцептивні здібності, вміти розуміти позицію інших, розуміти індивідуальність і неповторність іншої людини, емпатувати їй, рефлексувати. Крім того професія психолога супроводжується постійними перевантаженнями, психоемоційними напруженістю, емоційним вигоранням і т. п. Отже, найбільшу значущість у структурі особистості психолога мають емоційні здібності (емпатія, рефлексія, саморегуляція і управління почуттями та емоціями інших людей).

Аналіз досліджень та публікацій. За визначенням Даніеля Гоулмана, «емоційна компетентність - це здатність усвідомлювати і визнавати власні почуття, а також почуття інших, для самомотивації, для управління власними емоціями усередині себе і у стосунках 3 іншими». Емоційний інтелект як інтеграційна здатність людини до розуміння емоцій та 


\section{Питання психології}

управління ними розглядається вченими як засадничий чинник успішності життедіяльності людини (Cooper, Sawaf, 1997; Goleman, 1995; Weisinger, 1998); як передумова психічного і фізичного здоров'я (Е.Л. Носенко та ін., 2000; Ciarrochi, Dean, Anderson, 2002; Trinidad, Johnson, 2002; Bracett, Mayer, Warner, 2004); як умова ефективної комунікації і соціальної інтеракції (Schutte et al, 2001; I.М.Андрєєва, 2003; Власова, 2005). A.von Kanitz визначає рівні розвитку емоційної компетенції i вважає, що розпізнавання i розуміння власних емоцій (рефлексія) $є$ базовою компетенцією для ситуативного управління почуттями. Ця здатність $\epsilon$ основною передумовою для розвитку інших елементів емоційного інтелекту. T.I. Аврамова говорить про емоційно-особистісну компетентність і про можливість ії розвитку засобами тренінгу [1]. Г.В.Юсупова розглядає розумові здібності і компетентність як пов'язані з одними і тими ж психологічними механізмами [12]. Емоційна компетентність визначається нею в аспекті здібностей, що розвиваються, до саморегуляції і регуляції інтерперсональних стосунків шляхом розуміння власних емоцій та емоцій оточення. Вона виокремлює два компоненти емоційної компетентності, що мають внутрішній i зовнішній вектори спрямованості: когнітивний (розуміння емоцій) i поведінковий (управління емоціями). I.М.Андрєєва вважає, що структура емоційної компетентності $\epsilon$ більш деталізованою структурою емоційного інтелекту - iз врахуванням соціальних впливів на його розвиток [3].

Постановка завдання. Аналіз наукового доробку вчених, зусилля яких спрямовані на вивчення емоційної компетентності особистості.

Мета статті - аналіз стану дослідженості проблеми емоційної компетентності особистості у психологічному дискурсі.

Виклад основного матеріалу. Як відмічає І.В. Белашева, аналіз досліджень та авторських моделей показує, що емоційна компетентність пов'язана 3 емоційним інтелектом i грунтується на ньому: емоційний інтелект $\epsilon$ інструментом емоційної компетентності, оскільки є ментальною освітою, що проявляється у здатності діяти у згоді із внутрішнім середовищем власних почуттів та емоцій, розуміти стосунки особистості, що репрезентуються в емоціях, управляти емоційною сферою на основі інтелектуального аналізу i синтезу i використання емоцій для підвищення ефективності мислення і поведінки [4]. Емоційний інтелект визначає формування конкретних компетенцій в емоційній регуляції поведінки і діяльності: здатність чітко розпізнавати, що відчуває інша людина, він є основі розвитку компетенції впливу на переживання інших людей, здібності до толерантної взаємодії; здатність управляти своїми емоціями складає ядро розвитку таких компетенцій, як ініціативність, здатність працювати у стресовій ситуації, резилієнтність [6; 7].

Проведені О.М. Тимофєєвим дослідження із використанням методики оцінки A.von Kanitz 3 розвитку базової емоційної компетенції у студентів із різним рівнем розвитку загального інтелекту дали результати, які показують, що зайняття із студентами 2-го курсу впродовж одного семестру 3 розвитку базової емоційної компетенції (рефлексії) підвищує рівні розвитку емоційних компетенцій на 2-5\% i підвищує рівень розвитку рефлексії до 79\%, що впритул наближається до високого рівня розвитку базової емоційної компетенції [9]. Крім того, що чим вище рівень розвитку загального інтелекту студентів, тим вище початковий рівень емоційних компетенцій, що розвиваються у студентів. Таким чином, ментальність особистості як спосіб бачення світу, в якому думка не відокремлена від емоцій, визначає єдність інтелектуальної та емоційної компетентності.

О.С. Французова виокремлює основні складові емоційної компетентності: самосвідомість; самоконтроль, емпатія; навички стосунків [11]. Самосвідомість головний елемент емоційної компетентності. Людина із високою мірою самосвідомості знає власні сильні і слабкі сторони і вміє усвідомлювати власні емоції. Те, що вона самоусвідомила, означає глибоке розуміння самого себе, власних потреб і спонукань.

Самоконтроль самосвідомості. Людина, якій властива ця риса, не лише «пізнала себе», але i навчилася управляти собою i власними 


\section{Питання психології}

емоціями. Адже, попри те, що людськими емоціями рухають біологічні імпульси, вони цілком можуть управляти ними. Саморегуляція $є$ важливою складовою емоційної компетентності. Вона дозволяє людям не бути «заручниками власних почуттів». Такі люди завжди зуміють не лише приборкати власні емоції, але i спрямувати їх у корисне русло.

Якщо перші дві складові емоційної компетентності - це навички володіння собою, то наступні дві - емпатія i комунікабельність (навички стосунків) належать до здатності людини управляти взаємовідносинами 3 іншими. Успішна взаємодія з іншими людьми неможлива без емпатії. Це вміння ставити себе на місце іншого, враховувати в процесі ухвалення рішень почуття та емоції інших людей. Комунікабельність - здатність не така проста, адже це не просто дружелюбність, а дружелюбність із певною метою: спонукати людей у бажаному для людини напрямі. Це вміння налагодити взаємовідносини 3 іншими людьми так, щоб це було вигідно для обох сторін.

Оскільки емоційний інтелект, так само як i компетентність, трактується через поняття здатності, О.К. Хакімова і Р.О. Валеєва визнали правомірним вести мову про особливу психічну організацію індивіда - емоційну компетентність, що входить до складу емоційної складової особистісного компонента професійної компетентності психолога [10]. О.В. Лібіна, вивчаючи індивідуальні відмінності у реагуванні на стрес, вводить поняття емоційної компетентності, яку визначає як здатність особистості здійснювати оптимальну координацію між емоціями i цілеспрямованою поведінкою. Надалі автор розглядає понятя емоційної компетентності із точки зору психотерапевта, протиставляючи його захисній поведінці і при цьому залишаючи у тіні склад, структуру і властивості цього інтегрального утворення.

Г.В. Юсупова розглядає емоційну компетентність як групу здібностей, що розвиваються, до саморегуляції і регуляції інтерперсональних стосунків шляхом розуміння власних емоцій і емоцій оточення [12]. На iï думку розумові здібності i компетентність, досліджувані як різні, розглядаються як пов'язані з одними і тими ж психологічними механізмами. Вона виокремлює два компоненти емоційної компетентності: когнітивний (розуміння) i поведінковий (управління). Кожен компонент має два вектори: внутрішній спрямованість на себе i зовнішній спрямованість на інших. Когнітивний вектор спрямований, 3 одного боку, на саморозуміння, що означає як явище рефлексії, з іншого - при спрямованості на інших - на емоційно-когнітивну децентрацію власного «Я», відому як явище емпатії. Пристосувальні поведінкові реакції реалізуються через саморегуляцію поведінки (поведінковий вектор, спрямований на себе) і регуляцію стосунків 3 іншими (поведінковий вектор, спрямований на взаємодію з оточенням).

Відповідно у складі емоційної компетентності виокремлюються чотири базові компоненти 3 їхніми функціями: саморегуляція (контроль імпульсів та управління емоціями, вираження емоцій, блокування негативних емоційних станів); регуляція взаємовідносин (соціальні навички, вміння будувати стосунки 3 оточенням); рефлексія (самоусвідомлення, раціональне осмислення емоцій, виявлення власних мотивів); емпатія (емоційнокогнітивна децентрація). Попарна комбінація цих компонентів утворює чотири функціональні блоки емоційної компетентності: поведінковий блок (саморегуляція + регуляція стосунків 3 іншими); когнітивний блок (рефлексія + емпатія); інтраперсональний блок (саморегуляція + рефлексія); інтерперсональний блок (регуляція стосунків 3 іншими + емпатія). Коротко охарактеризуємо базові компоненти емоційної компетенції та їхнє значення в процесі міжособистісної взаємодії.

До рефлексії у загальному вигляді належать здібності людини визначати, яку саме емоцію вона відчуває у конкретний момент за фізичним станом i внутрішнім діалогом; співвідносити цю емоцію 3 iї назвою; визначати, 3 яких базових емоцій вона складається, усвідомлювати зміну інтенсивності емоції і переходи від однієї емоції до іншої. Рефлексія (саморозуміння) у цілому має емоційний, чуттєвий, емпатійний, а не раціональний характер. Отже, чим вище рівень розвитку емоційних здібностей, тим глибше саморозуміння, 


\section{Питання психології}

усвідомлення емоцій. Усвідомлення емоцій має на увазі їхню реєстрацію у свідомості. У свідомості не завжди реєструється той або інший емоційний процес. У зв'язку із цим необхідно розрізняти два явища. Перше явище $\epsilon$ достатньо відособленим організованим процесом, який суб'єктивно впливає на перебіг діяльності і пережите (у цьому випадку людина знає, що вона щось переживає, і це переживання відрізняється від попередніх). Друге явище - це власне усвідомлення, яке полягає у знанні про власний стан. Воно виражене у вербальних категоріях. Другий вид усвідомлення перебуває в основі процесів контролю над емоціями, в основі здатності передбачати їхній розвиток, знання чинників, від яких залежить їхня сила, тривалість і наслідки. Розуміння емоцій тісно пов'язане із можливостями їхнього вираження. Останне вимагає володіння мовою емоцій, засвоєння загальноприйнятих у цій культурі форм їхнього вираження, а також розуміння індивідуальних проявів емоцій у людей, 3 якими людина живе і працює.

У цілому під саморегуляцією розуміється вміння визначати джерело i причину виникнення емоції, іiі призначення i можливі наслідки розвитку, міру іiі корисності у конкретній ситуації; відповідно до цього при необхідності знайти спосіб регуляції емоції (зміни міри іiі інтенсивності або заміни на іншу емоцію), управляючи диханням, станом тіла, використовуючи вербальні і невербальні способи управління емоціями та управління внутрішнім діалогом. До цього ж вміння належить здатність викликати у себе емоцію, необхідну у конкретній ситуації. Адекватна емоційна експресія $є$ важливим чинником підтримки фізичного і психічного здоров'я. Стримування емоцій сприяє виникненню різних захворювань. У той же час безконтрольність емоційної експресії утрудняє міжособистісне спілкування. Мipa емоційної експресивності впливає i на якість міжособистісних стосунків. Так, надмірна стриманість призводить до того, що людина сприймається як холодна, байдужа, зарозуміла, що викликає у оточення здивування або неприязнь. Таким чином, проблеми у сфері саморегуляції $\epsilon$ несприятливими не лише для суб'єкта, але i для його найближчого оточення.
Регуляція взаємовідносин припускає вміння визначати можливу причину виникнення емоції у іншої людини i прогнозувати наслідки іiі розвитку; змінювати емоційний стан іншої людини (інтенсивності емоції, перехід на іншу емоцію) за допомогою вербальних i невербальних засобів; здатність викликати потрібну емоцію у людини.

Емпатія $є$ базисною складовою емоційної компетентності. Традиційно цей феномен розуміється як досягнення емоційного стану, співпереживання, занурення в емоційне життя іншої людини; це емоційний відгук людини на переживання інших людей, що проявляється як у співпереживанні, так і у співчутті. При співпереживанні емоційний відгук ідентичний тому, що і як переживає конкретна людина; при співчутті емоційний відгук виражається у співчутливому відношенні до того, що переживає. Емпатія містить розуміння іншої людини, що спирається на аналіз його особистості, емоційне співпереживання, відгук на почуття іншої людини і вираження власних почуттів, прагнення сприяти, допомагати іншій людині.

Терміном емпатія визначається не лише цей стан, але і особистісна риса здатність до такого роду розуміння i співпереживання. У сучасній психології розрізняють декілька видів емпатії: емоційну, яка грунтується на механізмах проекції i наслідування реакцій іншої людини; когнітивну, як таку, що базується на інтелектуальних процесах (порівняння, аналогія і т. п.), і предикативну - таку, що проявляється як здатність людини передбачати афективні реакції іншої у конкретних ситуаціях. Особливими формами емпатії вважаються співпереживання і співчуття - ототожнення iз почуттями іншої людини і переживання власних емоційних станів із приводу почуттів іншого. У психологічній літературі виокремллють три рівні емпатії.

Перший рівень (низький) пов'язаний із відсутністю інтересу до почуттів і думок інших. Людина не вміє i не бажає співпереживати людям. Другий рівень припускає епізодичну здатність до співпереживання, яка проявляється у деяких ситуаціях. Третій рівень емпатії (високий) означає глибоке і точне розуміння іншої 


\section{Питання психології}

людини, вміння подумки відтворити його переживання і відчуття як власні; глибокий такт, що дозволяє усвідомити власні проблеми і прийняти правильні рішення без жодного нав'язування власної думки або власних інтересів. Найглибший рівень - це «спосіб буття», який дозволяе розуміти нюанси і складнощі внутрішнього світу іншої людини.

Найбільш адекватне, системне розуміння поняття «емпатія» представлене у працях I.M. Юсупова, який вважає, що це цілісний феномен, який зв'язує між собою свідомі і підсвідомі рівні психіки, мета якого - «проникнення» у внутрішній світ іншої людини. У низці сучасних наукових праць емпатія розглядається як один із ключових чинників успішної професійної діяльності психолога як представника соціономічної професії [5]. Емпатія $є$ одним 3 найважливіших професійно значущих якостей особистості психолога, особливо це стосується проявів емпатії у спілкуванні із дітьми, бо передбачає вміння зрозуміти дитину, виразити їй власне співчуття i переживання, вміння співпереживати учневі, співчувати йому, проявляти доброзичливість, почуття причетності до усіх його «перемог» і «поразок».

Висновки. Синтезуючи здібності людини до усвідомлення власних емоцій і розуміння емоцій інших людей, емоційна компетентність забезпечує збереження душевного балансу, духовну цілісність і здоров'я особистості, проявляючись у ціннісній диференціації емоційних станів та емоційній саморегуляції діяльності i спілкування.
Розвиток цієї компетентності - складна робота, але саме ця робота дає найбільші результати, саме вона підвищує особисту ефективність. Інструментами розвитку емоційної компетентності є книги, тренінги, коучинг [2]. Між тим високі показники емоційної гнучкості ніколи не замінять ні професійної компетентності, ні вміння зважувати усе «за» i «проти» i робити об'єктивні висновки. На думку М.Рейнольдса «розвиток емоційної компетентності робить людину більш професіональною, а професіонала більш людяним» [8].

Психолог із високим рівнем розвитку емоційної компетентності має виражені здібності до розуміння власних емоцій та емоцій інших людей, до управління емоційною сферою, що обумовлює більш високу адаптивність і ефективність у спілкуванні. Емоційна компетентність, як складова професійної компетентності, $є$ сукупністю емоційних i соціальних здібностей, таких як здібності до розуміння власних емоцій та емоцій інших людей, до управління емоційною сферою. Усі структурні компоненти емоційної компетентності взаємозв'язані, і їхня тісна взаємозалежність сприяє ефективній міжособистісній взаємодії. Розвинена емоційна компетентність - найважливіша якість високопрофесійного психолога. Якщо людина володіє високим IQ, але його EQ дуже низький, навряд чи вона зможе бути успішною. Адже робота психолога як представника соціономічної професії складається із спілкування, успіх якого безпосередньо залежить від коефіцієнта емоційного інтелекту, на якому грунтується емоційна компетентність.

\section{Список використаних джерел}

1. Аврамова Т.И. Развитие эмоционально-личностной компетентности средствами тренинга у студентов. Акмеология. 2015. №3. С. 20-21.

2. Азлецкая, Е.Н. Как сформировать эмоциональную компетентность. Директор икольы. 2006. N1. C. 35-36.

3. Андреева И.Н. Эмоциональный интеллект: исследования феномена. Вопросы психологии. 2006. №3. С. $78-86$.

4. Белашева И.В. Эмоциональная компетентность как критерий и ресурс психологического здоровья личности. Акмеология. 2016. №3. С. 143-152.

5. Журавльова Л.П. Психологічні основи розвитку емпатії людини: дис. д-ра психол. наук. Південноукраїнський державний педагогічний університет ім. К.Д. Ушинського, Одеса, 2008. 391 с.

6. Мавлянова О.В. Эмоциональная компетентность и целенаправленность поведения детей младшего школьного возраста с разными формами проявления агрессии: дисс. канд. психол. наук M., 2011. 269 c.

7. Мохряков М.О. Эмоциональная компетентность и её компоненты в структуре требований к результатам освоения основной образовательной программы начального общего образования 


\title{
Питання психології
}

младших школьников с общим недоразвитием речи. Научно-методический электронный журнал «Кониепт». 2016. T.17. С. 398-403. URL: http://e-koncept.ru/2016/46255.htm

8. Рейнольдс М. Коучинг: эмоциональная компетентность. / Пер. с англ. Центра поддержки корпоративного управления и бизнеса - Центр поддержки корпоративного управления и бизнеса. M., 2003. $112 \mathrm{c}$.

9. Тимофеев О.Н. Эмоциональная компетентность и профессиональная компетентность. Вестник Казанского технологического университета. 2011. Т.14. №2. С. 318-323.

10. Хакимова Е.К., Валеева Р.А. Эмоциональная компетеность в структуре профессиональной компетенотности педагога-психолога. Современные проблемы науки и образования. 2014. №1. URL: http://www.science-education.ru/ru/article/view?id=12142

11. Французова О.Е. Эмоциональная компетентность личности как предмет исследования. Гаудеамус: психолого-педагогический журнал. Тамбов: ТГУ им. Г.Р. Державина, 2016. Т.15. №3. С. 114-117.

12. Юсупова Г. В. Состав и измерение эмоциональной компетентности: дис. ... канд. психол. наук. Казань. 2006. 208 с.

13. Cherniss C. Social and Emotional Competence in the Workplace. In: R.BarOn, J.D.A.Parker (Eds.). Handbook of emotional intelligence: Theory, development, assessment, and application at home, school, and in the workplace. San Francisco, CA: Jossey-Bass, 2000. pp. 433-458.

\section{References}

1. Avramova T.I. Razvitie jemocional'no-lichnostnoj kompetentnosti sredstvami treninga $u$ studentov. Akmeologija. 2015. №3. S. 20-21. $35-36$.

2. Azleckaja, E.N. Kak sformirovat' jemocional'nuju kompetentnost'. Direktor shkoly. 2006. №1. S.

3. Andreeva I. N. Jemocional'nyj intellekt: issledovanija fenomena. Voprosy psihologii. 2006. №3. S. $78-86$.

4. Belasheva I.V. Jemocional'naja kompetentnost' kak kriterij i resurs psihologicheskogo zdorov'ja lichnosti. Akmeologija. 2016. №3. S. 143-152.

5. Zhuravl'ova L.P. Psyhologichni osnovy rozvytku empatii' ljudyny: dys. d-ra psyhol. nauk. Pivdennoukrai'ns'kyj derzhavnyj pedagogichnyj universytet im. K.D. Ushyns'kogo, Odesa, 2008. $391 \mathrm{~s}$.

6. Mavljanova O.V. Jemocional'naja kompetentnost' i celenapravlennost' povedenija detej mladshego shkol'nogo vozrasta s raznymi formami projavlenija agressii: diss. kand. psihol. nauk M., 2011. 269 c.

7. Mohrjakov M.O. Jemocional'naja kompetentnost' i ejo komponenty v strukture trebovanij k rezul'tatam osvoenija osnovnoj obrazovatel'noj programmy nachal'nogo obshhego obrazovanija mladshih shkol'nikov s obshhim nedorazvitiem rechi. Nauchno-metodicheskij jelektronnyj zhurnal «Koncept». 2016. T.17. S. 398-403. URL: http://e-koncept.ru/2016/46255.htm

8. Rejnol'ds M. Kouching: jemocional'naja kompetentnost'. / Per. s angl. Centra podderzhki korporativnogo upravlenija i biznesa - Centr podderzhki korporativnogo upravlenija i biznesa. M., 2003. $112 \mathrm{~s}$.

9. Timofeev O.N. Jemocional'naja kompetentnost' i professional'naja kompetentnost'. Vestnik Kazanskogo tehnologicheskogo universiteta. 2011. T.14. №2. S. 318-323.

10. Hakimova E.K., Valeeva R.A. Jemocional'naja kompetenost' v strukture professional'noj kompetenotnosti pedagoga-psihologa. Sovremennye problemy nauki i obrazovanija. 2014. №1. URL: http://www.science-education.ru/ru/article/view?id=12142

11. Francuzova O.E. Jemocional'naja kompetentnost' lichnosti kak predmet issledovanija. Gaudeamus: psihologo-pedagogicheskij zhurnal. Tambov: TGU im. G.R. Derzhavina, 2016. T.15. №3. S. 114-117.

12. Jusupova G.V. Sostav i izmerenie jemocional'noj kompetentnosti: dis. ... kand. psihol. nauk. Kazan'. 2006. 208 s.

13. Cherniss C. Social and Emotional Competence in the Workplace. In: R.BarOn, J.D.A.Parker (Eds.). Handbook of emotional intelligence: Theory, development, assessment, and application at home, school, and in the workplace. San Francisco, CA: Jossey-Bass, 2000. pp. 433-458.

\author{
Резюме \\ Гичко Ю. аспирант Уманского государственного \\ педагогического университету им. Павла Тычини \\ ORSID ID 0000000212511129 \\ ЭМОЦИОНАЛЬНАЯ КОМПЕТЕНТНОСТЬ ЛИЧНОСТИ В ПСИХОЛОГИЧЕСКОМ \\ ДИСКУРСЕ
}




\section{Питання психології}

В статье презентованы результаты анализа научного вклада ученых, усилия которых направлены на изучение эмоциональной компетентности личности. В частности, отмечается, что синтезируя способности человека к осознанию собственных эмоций и пониманию эмоцчий других людей, эмочиональная компетентность обеспечивает сохранение душевного баланса, духовную целостность и здоровье личности, проявляясь в ценностной дифференцииачи эмоциональньх состояний $и$ эмоциональной саморегуляциии деятельности и общения. Развитие этой компетентности - сложная работа, но именно эта работа дает наибольшие результаты, именно она повышает личную эффективность. Психолог с высоким уровнем развития эмоциональной компетентности имеет выраженные способности к пониманию собственных эмоций и эмоций других людей, к управлению эмоциональной сферой, которая обусловливает высшую адаптивность u эффективность в общении. Эмочиональная компетентность, как составляющая профессиональной компетентности, является совокупностью эмоциональных и социальных способностей, таких как способности к пониманию собственньх эмоций и эмоџий других людей, к управлению эмочиональной сферой. Все структурные компоненть эмоциональной компетентности взаимосвязаны, и их тесная взаимозависимость способствует эффективному межличностному взаимодействию. Инструментами развития эмоциональной компетентности являются книги, тренинги, коучинг.

Ключевые слова: эмоциональная компетентность; личность; эмоциональные состояния; эмоциональная саморегуляція; деятельность; общение.

\section{Summary \\ Hychko $\boldsymbol{Y}$. PhD student of the Uman state pedagogical university named by Pavlo Tuchina, Uman city \\ EMOTIONAL COMPETENCE OF PERSONALITY IN PSYCHOLOGICAL DISCURS}

In the article presented the results of analysis of scientific benefit of scientists, which efforts directed to research of emotional competence of personality. In particular, marked, that the specific of labour of psychologist consists in that he must resist to professional difficulties, to manage an emotional eigenstate, to determine the features of own actions, show perception capabilities, able to understand position other, to understand individuality and uniqueness of other man, to empathy to him, to reflecting. In addition the profession of psychologist is accompanied by permanent psychoemotion overloads, emotional tension, emotional burning down and $m$. $n$. Psychologist with the high level of development of emotional competence has the expressed capacities for understanding of own emotions and emotions of other people, to the management an emotional sphere that stipulates a higher adaptivity and efficiency in communication. An emotional competence, as a constituent of professional competence, is totality of emotional and social capabilities, such as capacities for understanding of own emotions and emotions of other people, to the management an emotional sphere. Thus, emotional capabilities (empathy, reflection, self-regulation and management feelings and emotions of other people) have most meaningfulness in the structure of personality of psychologist.

Synthesizing the capacities of man for realization of own emotions and understanding of emotions of other people, an emotional competence provides maintenance of heartfelt balance, spiritual integrity and health of personality, showing up in the valued differentiation of the emotional states and emotional selfregulation of activity and communication. Development of this competence is difficult work, but exactly this work gives most results, exactly she promotes the personal efficiency.

In composition an emotional competence four base components are distinguished with their functions: self-regulation (control of impulses and management, expression of emotions, blocking of the negative emotional states, emotions); adjusting of mutual relations (social skills, abilities to build relationships with surroundings); reflection (selfconsciousnessing, rational comprehension of emotions, exposure of own reasons); empathy (emotionally-cognitive decentration). Combination on pairs of these components forms four function boxes of emotional competence: behavioral block (self-regulation + adjusting of relationships with other); cognitive block (reflection + empathy); intrapersonal block (selfregulation + reflection); interpersonal block (adjusting of relations with other + empathy). All structural components of emotional competence are associate, and their close interdependence assists effective cooperation between personalities. The instruments of development of emotional competence are books, training, couching.

Key words: emotional competence, personality, emotional states, emotional self-regulation, activity, communication. 